\title{
Management of patients with ST-elevation myocardial infarction at a COVID dedicated hospital
}

\author{
BBiljana Šego ${ }^{*}$, \\ OMirjana Slanc', \\ CMirela Adamović', \\ DZoran Marić', \\ OIvana Jelinek', \\ OMatija Vrbanić', \\ -Kristijana Radić', \\ (ilvica Benko',2, \\ -Ljiljana Švađumović', \\ Clatka Funduk'
}

${ }^{1}$ Klinička bolnica Dubrava, Zagreb, Hrvatska

2Zdravstveno veleučilište Zagreb, Zagreb, Hrvatska 'University Hospital Dubrava, Zagreb, Croatia 'University of Applied Health Sciences, Zagreb, Croatia

\section{RECEIVED:}

September 7, 2021

ACCEPTED:

September 14, 2021

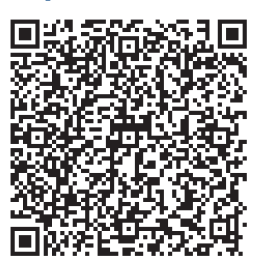

$\square$ Cardiologia Croatica 2021;16(11-12):372.

\author{
KEYWORDS: COVID-19, acute coronary syndrome, STEMI management. \\ CITATION: Cardiol Croat. 2021;16(11-12):372. | https://doi.org/10.15836/ccar2021.372 \\ *ADDRESS FOR CORRESPONDENCE: Biljana Šego, Klinička bolnica Dubrava, Avenija Gojka Šuška 6, HR-10000 \\ Zagreb, Croatia. / Phone +385-1-290-2545 / E-mail: bsego@kbd.hr \\ ORCID: Biljana Šego, https://orcid.org/0000-0002-0806-1233 • Mirjana Slanc, https://orcid.org/0000-0002-6247-4696 \\ Mirela Adamović, https://orcid.org/0000-0003-4922-7436 • Zoran Marić, https://orcid.org/0000-0002-9121-4631 \\ Ivana Jelinek, https://orcid.org/0000-0003-4315-888x • Matija Vrbanić, https://orcid.org/0000-0002-3229-9436 \\ Kristijana Radić, https://orcid.org/0000-0002-6098-254X • Ivica Benko, https://orcid.org/0000-0002-1878-0880 \\ Ljiljana Švađumović, https://orcid.org/0000-0002-9068-2716 • Vlatka Funduk, https://orcid.org/0000-0001-7070-188x
}

\section{|IIIIIIIIIIIIIIIIIIIIIIIIIIIIIIIIIIIIIIIIIIIIIIIIIIIIIIIIIIIIIIIIIIIIIIIIIIIIIIIIIIIIIIIIIIIIIIIIIIIIIIIIIIIIIIIIIII}

The COVID-19 pandemic has posed new challenges in the treatment of acute coronary syndrome for several reasons. COVID-19 primarily affects the respiratory system, but in patients with risk factors (arterial hypertension, diabetes, obesity, underlying cardiovascular disease) it can cause severe respiratory failure, thrombotic events, and worsening of cardiovascular status. Diagnosis and treatment of patients with acute myocardial infarction during a pandemic can be hampered by anti-epidemic measures taken to prevent transmission to patients and medical staff, patients' fear of disease, health system burden, and staff occupancy, all of which can slow timely medical response., ${ }^{1,2}$ The first experiences and recommendations with patients with ST-elevation myocardial infarction (STEMI) and COVID-19 were unclear, but since November 2020, the recommendations of the European Society of Cardiology emphasize adherence to all previous guidelines for the treatment of STEMI patients with the aim of early and successful reperfusion, but with mandatory use of personal protection equipment and masks for both patients and staff.

We present our experiences with the treatment of patients with acute myocardial infarction who were positive for SARS-CoV-2 or had already developed moderate or severe symptoms. Since the 3rd wave of the epidemic, University Hospital Dubrava was organized as a COVID-19 dedicated hospital for patients with severe symptoms with or without serious comorbidities in the City of Zagreb and 6 surrounding counties. The clinical characteristics and outcomes of patients with STEMI and specifics in the treatment management of these patients and medical staff are presented.
LITERATURE IIIIIIIIIIIIIIIIIIIIIIIIIIIIIIIIIIIIIIIIIIIIIIIIIIIIIIIIIIIIIIIIIIIIIIIIIIIIIIIIIIIIIIIIIIIIIIIIIIIIIIIIII

1. Postupnik dijagnostike i liječenja akutnog infarkta miokarda Hrvatskoga kardiološkog društva (12/2020.). Cardiol Croat. 2021;16(1-2):86. Croatian. Available at: https://www.kardio.hr/pdf/Cardiologia\%20croatica\%202021\%2016_1-2_86.pdf (September 1, 2020).

2. BabićZZ, Margetić E, Miličcí D. Primary Percutaneous Coronary Intervention during the COVID-19 Pandemic. Cardiol Croat. 2020;15(5-6):91-6. https://doi.org/10.15836/ccar2020.91 